\title{
Peroxisome proliferator-activated receptor- $\gamma$ haploinsufficiency enhances B cell proliferative responses and exacerbates experimentally induced arthritis
}

\author{
Keigo Setoguchi, ${ }^{1}$ Yoshikata Misaki, ${ }^{1}$ Yasuo Terauchi, ${ }^{2}$ Toshimasa Yamauchi, ${ }^{2}$ \\ Kimito Kawahata, ${ }^{1}$ Takashi Kadowaki, ${ }^{2}$ and Kazuhiko Yamamoto ${ }^{1}$ \\ ${ }^{1}$ Department of Allergy and Rheumatology, and \\ ${ }^{2}$ Department of Metabolic Diseases, University of Tokyo Graduate School of Medicine, Tokyo, Japan \\ Address correspondence to: Yoshikata Misaki, Department of Allergy and Rheumatology, \\ University of Tokyo Graduate School of Medicine, Tokyo, Japan. \\ Phone: 81-3-3815-5411; Fax: 81-3-3815-5954; E-mail address: misaki-tky@umin.ac.jp.
}

Received for publication May 4, 2001, and accepted in revised form October 8, 2001.

\begin{abstract}
Peroxisome proliferator-activated receptor- $\gamma(\operatorname{PPAR} \gamma)$ controls adipogenesis and glucose metabolism. It was reported recently that PPAR $\gamma$ activation by its agonistic ligands modifies lymphocyte function. Since synthetic ligands are known to exert their effect via PPAR $\gamma$-dependent and -independent pathways, we examined the physiological role of PPAR $\gamma$ in lymphocytes by using heterozygote mutant mice in which one allele of PPAR $\gamma$ is deleted $\left(P P A R \gamma^{+/}\right)$. In contrast to T cells, which did not exhibit a significant difference, B cells from $P P A R \gamma^{+/}$showed an enhanced proliferative response to stimulation by either lipopolysaccharide or cross-linking of antigen receptors. Dysregulation of the NF- $\mathrm{KB}$ pathway in B cells from $P P A R \gamma^{+/-}$was indicated by spontaneous NF- $\kappa B$ activation, as well as increased $\mathrm{I} \kappa \mathrm{B} \alpha$ phosphorylation and gel-shift activity following LPS stimulation. Mice primed with either ovalbumin or methylated BSA also showed enhanced antigen-specific immune response of both $T$ and $B$ cells, an immunological abnormality that exacerbated antigen-induced arthritis. These findings indicate that PPAR $\gamma$ plays a critical role in the control of B cell response and imply a role in diseases in which B cell hyperreactivity is involved, such as arthritis and autoimmunity.
\end{abstract}

J. Clin. Invest. 108:1667-1675 (2001). DOI:10.1172/JCI200113202.

\section{Introduction}

Peroxisome proliferator-activated receptor- $\gamma(\operatorname{PPAR} \gamma)$ is one of the isotypes of peroxisome proliferator-activated receptors, which are a group of closely related nuclear receptors. The primary role of PPAR $\gamma$, which is mainly expressed in adipose tissue, is to promote lipogenesis under anabolic conditions (1-6). PPAR $\gamma$ is expressed in various other tissues, including colon, retina, and spleen, although in lesser amounts $(2,6)$. PPAR $\gamma$ is also known to regulate inflammatory responses. In monocytes and monocyte-derived macrophages, activation of PPAR $\gamma$ inhibits the expression of such inflammatory cytokines as TNF- $\alpha$, IL- $1 \alpha$, and IL-6 $(7,8)$. It was reported recently that PPAR $\gamma$ activation modifies lymphocyte function. Agonistic ligands for PPAR $\gamma$ inhibit proliferation of $T$ helper cell clones (9-11) as well as B cells and B cell lymphoma cells $(12,13)$. PPAR $\gamma$ ligands are even cytotoxic for B cells by induction of apoptosis. These findings led to the proposal that manipulation of PPAR $\gamma$ has potential as a therapeutic strategy for controlling inflammatory and immunological diseases (6).

Most studies described above employed PPAR $\gamma$ agonists, such as 15 -deoxy- $\Delta^{12,14}$-prostaglandin $\mathrm{J}_{2}(15 \mathrm{~d}$ $\mathrm{PGJ}_{2}$ ) and thiazolidinediones (TZDs), both of which have affinity for PPAR $\gamma(3,4,14,15)$. It was demonstrated that the anti-inflammatory and antiprolifera- tive effects of PPAR $\gamma$ activation by these ligands are involved in suppression of NF- $\mathrm{KB}$, which is a key transcription factor for proliferation, apoptosis, and cytokine synthesis of inflammatory cells $(7,8)$. Straus et al. reported that $15 \mathrm{~d}-\mathrm{PGJ}_{2}$ inhibits multiple steps in the NF- $\mathrm{KB}$ signaling pathway (16). Another study also suggested that $15 \mathrm{~d}_{-} \mathrm{PGJ}_{2}$ directly regulates NF- $\mathrm{KB}$ as well as IKK $\beta$ (17). Interestingly, in those studies that used PPAR $\gamma$ agonists on lymphocytes, $15 \mathrm{~d}_{-} \mathrm{PGJ}_{2}$ always showed more efficient suppression of lymphocytes and induction of apoptosis than other ligands (9-13), indicating that $15 \mathrm{~d}-\mathrm{PGJ}_{2}$ exhibits its effect not only via PPAR $\gamma$ but also via other pathways. Finally, Chawla et al. reported that both $15 \mathrm{~d}-\mathrm{PGJ}_{2}$ and TZDs exert antiinflammatory effect in macrophages derived from mice homozygous for a null mutation in the PPAR $\gamma$ gene, indicating that they can work by a PPAR $\gamma$-independent mechanism (18). PPAR $\gamma$ expression is dispensable for some function of macrophages including differentiation of the macrophage lineage and lipid metabolism (18). Therefore, it is possible that the role of PPAR $\gamma$ in lymphocytes is overestimated since the ligands are used at concentrations exceeding those required to bind $\operatorname{PPAR} \gamma(18)$.

Rheumatoid arthritis (RA) is a representative systemic chronic inflammatory disease in the pathogenesis of which immunological abnormalities, including 
autoimmune responses, are also involved. Persistent inflammation in hyperplastic synovium and pannus accompanied by massive cell infiltration in joints finally leads to the destruction of cartilage and bone (19). T cells infiltrate massively into the pannus and expand clonally in the synovium and synovial fluid $(20,21)$. Lymphoid follicles composed mainly of B cells are also formed in the pannus, and rheumatoid factor as well as hypergammaglobulinemia are the prominent serological features of RA (22).

Recently, it was reported that PPAR $\gamma$ agonistic ligands, $15 \mathrm{~d}_{-} \mathrm{PGJ}_{2}$ and troglitazone, could ameliorate adjuvantinduced arthritis in rats, which is an experimental model of RA (23). The authors addressed that the PPAR $\gamma$ agonistic ligands regulate the inflammation in the synovial macrophages and synovial cells to exhibit their therapeutic effects since apoptosis is induced in synovial cells by PPAR $\gamma$ ligands in vitro and synovial macrophages express PPAR $\gamma$. We suspect that not only modification of immunological components but also PPAR $\gamma$-independent effect of the PPAR $\gamma$ agonistic ligands might also contribute to the amelioration, since adjuvant arthritis involves immunological pathogenic mechanisms.

We have generated PPAR $\gamma$ gene-targeted mice (24). Complete elimination of a functional PPAR $\gamma$ gene results in embryonic lethality, whereas PPAR $\gamma$ heterozygote knockout mice $\left(\mathrm{PPAR} \gamma^{+-}\right)$exhibit resistance to high-fat diet-induced obesity and insulin resistance (24, $25-27)$. This heterozygote shows a $50 \%$ reduction in $\operatorname{PPAR} \gamma(24,25)$. This PPAR $\gamma$ mutant permits us to investigate the physiological role of PPAR $\gamma$ in the immune system without employing PPAR $\gamma$ synthetic agonists. We found that haploinsufficiency of PPAR $\gamma$ affects B cells but not $\mathrm{T}$ cells. The $\mathrm{B}$ cell proliferative response was enhanced in PPAR $\gamma^{+/}$. These results indicate that PPAR $\gamma$ plays a critical role in regulating homeostasis of B cell function. Furthermore, the antigen-specific immune response is enhanced in PPAR $\gamma^{+-}$, probably due to $\mathrm{B}$ cell hyperreactivity. Finally, when we induced arthritis experimentally, the arthritis in PPAR $\gamma^{+/}$was exacerbated compared with wild-type. These findings provide new insight into the physiological role of PPAR $\gamma$ in the immune system and its pathogenic role in arthritis and autoimmune diseases since B cell hyperreactivity is involved in the pathogenesis of these diseases.

\section{Methods}

Animals. The generation of PPAR $\gamma$ gene-targeted mice was described previously (24). Heterozygous PPAR $\gamma$ deficient mice were crossed to the ICR background for more than eight generations and were maintained in a temperature- and light-controlled environment with free access to food and water under specific-pathogen free (SPF) conditions. Female, age-matched mice were used in all experiments, and the mice were 7-10 weeks old at the start of each experiment. For each experiment littermates were used as a control. ICR mice for mating were obtained from Japan SLC Inc. (Hamamatsu, Shizuoka, Japan).
Materials. The $15 \mathrm{~d}-\mathrm{PGJ}_{2}$ was obtained from Cayman Chemical (Ann Arbor, Michigan, USA). Troglitazone, pioglitazone, and rosiglitazone (BRL49653) were kindly donated by Sankyo Co. (Toyko, Japan), Takeda Chemical Industries Ltd. (Osaka, Japan), and GlaxoSmithKline (Greenford, Middlesex, United Kingdom) respectively. Ovalbumin (OVA), methylated-BSA (mBSA), and lipopolysaccharide (LPS) were obtained from Sigma Chemical Co. (St. Louis, Missouri, USA). Anti-mouse $\operatorname{IgM~F}\left(\mathrm{ab}^{\prime}\right)_{2}$ was obtained from Jackson Immunoresearch Laboratories Inc. (West Grove, Pennsylvania, USA).

Lymphocyte proliferation assay. Single cell suspension from splenocytes or lymph nodes was cultured at $10^{5}$ cells/well with various concentrations of OVA and mBSA in RPMI-1640 medium supplemented with 2 $\mathrm{mM}$ L-glutamine, $100 \mathrm{U} / \mathrm{ml}$ penicillin, $100 \mu \mathrm{g} / \mathrm{ml}$ streptomycin, $10 \%$ heat-inactivated FCS, and $5 \times 10^{-5} \mathrm{M}$ 2 -mercaptoethanol (2-ME) for 5 days. This was followed by a final 16 hours of culture in the presence of $1 \mu \mathrm{Ci}$ of $\left[{ }^{3} \mathrm{H}\right]$ thymidine per well. The incorporated radioactivity was counted with a $\beta$-scintillation counter. The proliferative response was expressed as the mean cpm of test cultures \pm SD.

Naive T cells were purified using a MACS (Miltenyi Biotech GmbH, Bergisch Gladbach, Germany), as described previously $(28,29)$. They were stimulated with 1 or $10 \mu \mathrm{g} / \mathrm{ml}$ of anti-CD3 $\mathrm{Ab}$ in the presence of $1 \mu \mathrm{g} / \mathrm{ml}$ of anti-CD28 Ab for 24 hours. Proliferation was measured by $\left[{ }^{3} \mathrm{H}\right]$ thymidine incorporation (30).

$\mathrm{B}_{220^{+}}$spleen cells were isolated using a MACS according to the manufacturer's instructions. Purified B cells were cultured at $10^{5}$ cells/well in RPMI-1640 with $10 \%$ heat-inactivated FCS. Cells were incubated for 56 hours with $10 \mu \mathrm{g} / \mathrm{ml}$ of LPS or $20 \mu \mathrm{g} / \mathrm{ml}$ of goat anti-mouse $\operatorname{IgM~F}\left(\mathrm{ab}^{\prime}\right)_{2}(31)$. One $\mu \mathrm{Ci}$ of $\left[{ }^{3} \mathrm{H}\right]$ thymidine was added per well for the final 16 hours. Cells were harvested and counted with a scintillation counter as $\mathrm{T}$ cells. The purity of fractionated cells was monitored by an EPIX-system II (Coulter Electronics Ltd., Hialeah, Florida, USA) using anti-CD3 and anti-B220 (RA39B2) (PharMingen, San Diego, California, USA).

Quantitation of cytokines. IFN- $\gamma$ and IL-2 in the supernatant of mBSA-stimulated T cells from the mice primed with mBSA were quantified using sandwich ELISA kits (Endogen Inc., Woburn, Massachusetts, USA).

$A b$ assay. The level of anti-OVA or anti-mBSA Ab in sera was measured by ELISA as described previously (29).

Examination of cell viability. Viable cells were counted by trypan blue-exclusion method. For propidium iodide (PI) staining, cells were washed with PBS and fixed in $80 \%$ ethanol/PBS. After fixation, cells were washed again and then incubated with $500 \mu \mathrm{g} / \mathrm{ml}$ DNase-free RNase, $20 \mu \mathrm{g} / \mathrm{ml}$ PI for 30 minutes at $37^{\circ} \mathrm{C}$. Thereafter, sub-G0 peaks, which correspond to dead or dying cells, were determined using a flow cytometer $(32,33)$.

Electrophoretic mobility shift assay. Electrophoretic mobility shift assays (EMSAs) were performed as described previously (34). Briefly, $10^{7}$ cells were washed with cold PBS and resuspended in buffer A (10 mM HEPES, pH 


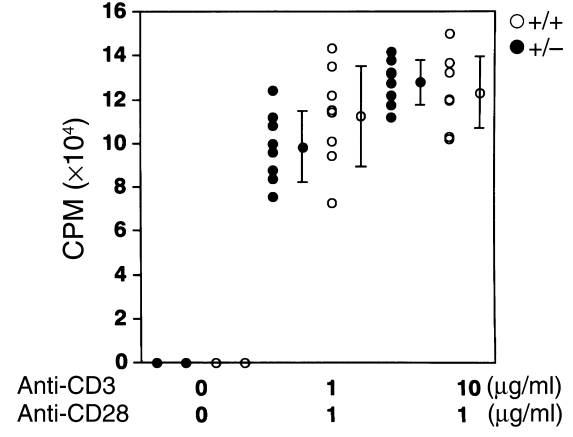

Figure 1

Proliferative response of naive T cells from PPAR $\gamma^{+/-}$mice does not differ from wild-type mice. T cells were purified from the spleen of each naive mouse and stimulated with 1 or $10 \mu \mathrm{g} / \mathrm{ml}$ of anti-CD3 Ab in the presence of $1 \mu \mathrm{g} / \mathrm{ml}$ of anti-CD28 Ab for 24 hours. The proliferation was measured by $\left[{ }^{3} \mathrm{H}\right]$ thymidine incorporation. Bars show the mean \pm SD ( $n=8$ per group). Data from every littermate group of PPAR $\gamma^{+/-}$and PPAR $\gamma^{+/+}$mice were statistically analyzed. There was no significant difference in the naive $T$ cell response between the PPAR $\gamma^{+/-}$mice (filled circles, +/-) and the littermate ICR (open circles, $+/+$ ) wild-type mice.

7.9, $1.5 \mathrm{mM} \mathrm{MgCl} 2,10 \mathrm{mM} \mathrm{KCl}$, and $0.5 \mathrm{mM}$ DTT) with $0.1 \%$ Nonidet P-40 and protease inhibitors (leupeptin, aprotinin, and $\mathrm{PMSF}$ ) at $0^{\circ} \mathrm{C}$ for 10 minutes, followed by centrifugation and resuspension of the nuclear pellet in buffer C (20 mM HEPES, pH 7.9, 25\% glycerol, $0.42 \mathrm{M} \mathrm{NaCl}, 1.5 \mathrm{mM} \mathrm{MgCl}_{2}, 0.2 \mathrm{mM}$ EDTA, and 0.5 $\mathrm{mM}$ DTT) with protease inhibitors at $0^{\circ} \mathrm{C}$ for $20 \mathrm{~min}$ utes. To remove insoluble debris, nuclear lysates were centrifuged and stored at $-80^{\circ} \mathrm{C}$. The NF- $\mathrm{KB}$-binding sequence (Promega Corp., Madison, Wisconsin, USA) was labeled using T4 kinase. The nuclear lysates were incubated with a ${ }^{32} \mathrm{P}$-labeled probe in DNA-binding buffer for 20 minutes at room temperature before electrophoresis in a $4 \%$ polyacrylamide gel.

I $\kappa$ immunoblot. Cells were lysed in NP-40 lysis buffer containing 1\% NP-40, 20 mM Tris- $\mathrm{HCl}$ (pH 7.4), 150 $\mathrm{mM} \mathrm{NaCl}, 1 \mathrm{mM}$ EDTA, $1 \mathrm{mM}$ PMSF, $10 \mathrm{mM} \mathrm{NaF}, 0.5$ $\mathrm{mM} \mathrm{Na}_{3} \mathrm{VO}_{4}, 10 \mu \mathrm{g} / \mathrm{ml}$ aprotinin, and $10 \mu \mathrm{g} / \mathrm{ml} \mathrm{leu-}$ peptin. The same amount of protein in each sample was separated by SDS-PAGE on $12.5 \%$ gel and transferred to a nitrocellulose membrane (Schleicher \& Schnell GmbH, Dassel, Germany) (34). Blots were incubated with either rabbit anti-phospho-IкB $\alpha \mathrm{mAb}$ or rabbit anti-IKB $\alpha \mathrm{mAb}$ (Cell Signaling Technology, Beverly, Massachusetts, USA). After washing, blots were incubated with anti-rabbit Ig Ab coupled with peroxidase and visualized by the enhanced chemiluminescence (ECL) system (Amersham Pharmacia Biotech, Buckinghamshire, United Kingdom).

Induction of AIA. Mice were immunized intradermally at the base of the tail with $100 \mu \mathrm{g}$ of mBSA dissolved in $100 \mu \mathrm{l}$ of PBS and emulsified with an equal volume of CFA (Difco Laboratories, Detroit, Michigan, USA) (day 0 ) as described previously (29). Fourteen days later, 20 $\mu \mathrm{g}$ mBSA dissolved in $20 \mu \mathrm{l}$ of PBS was injected intra- articularly into the left ankle joint. The right ankle joint was injected with $20 \mu \mathrm{l}$ PBS only as a negative control. The joint thickness was measured with dial-gauge calipers (Mitutoyo, Kawasaki, Kanagawa, Japan). The net increase in joint thickness attributable to the antigenic challenge was calculated by subtracting the increase in thickness of the right ankle from the increase in thickness of the left ankle.

Histology. Ankles and knees were fixed in 10\% phosphate-buffered formalin and decalcified. Tissues were then dehydrated in a gradient of alcohols, paraffinembedded, sectioned, mounted on glass slides, and stained with hematoxylin and eosin (29).

Statistical analysis. Statistical evaluation was performed with both paired $t$ test and Mann-Whitney's $U$ test. In addition to statistical analysis using the whole samples, to decrease the genetic variance due to the ICR background we also compared the data of PPAR $\gamma^{+/-}$mice with that of their PPAR $\gamma^{+/+}$littermates derived from the same litter.

\section{Results}

$T$ cell from PPAR $\gamma^{\dagger-}$ mice appeared to be normal. The immune system of PPAR $\gamma^{+/-}$mice developed normally, since the size of the thymus and spleen, the number of $T$ cells in both the thymus and spleen, the ratio of CD4/CD8 $\mathrm{T}$ cells, and the number of B cells in the spleen were not different from those of wild-type mice (data not shown).

To investigate the influence of the reduced amount of PPAR $\gamma$ in PPAR $\gamma^{+-}$mice on the function of lymphocytes, first we examined $T$ cell function, since it has been reported that PPAR $\gamma$ agonists inhibit proliferation of Thelper cell clones (9-11). To verify this, we stimulated purified naive T cells with anti-CD3 and anti-CD28 Ab.
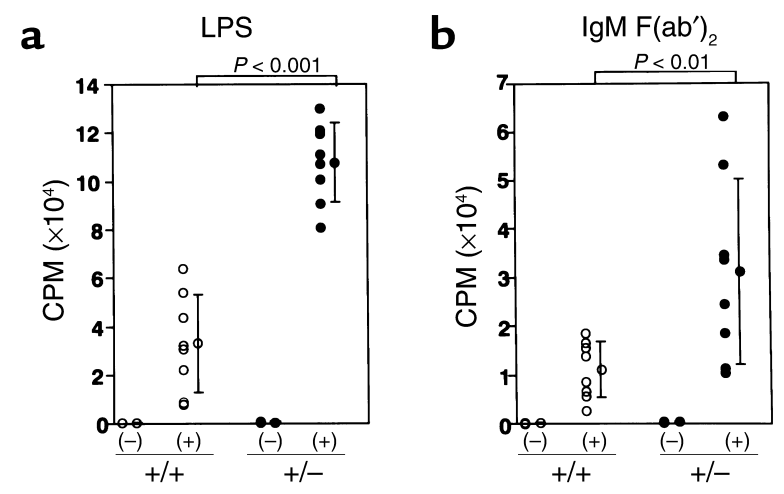

\section{Figure 2}

Enhanced proliferative response of B cells from PPAR $\gamma^{+/-}$mice. Naive $B$ cells $\left(10^{5}\right)$ purified from the spleen of each mouse were stimulated with either $10 \mu \mathrm{g} / \mathrm{ml}$ of LPS (a) or $20 \mu \mathrm{g} / \mathrm{ml}$ of anti-mouse IgM F $\left(\mathrm{ab}^{\prime}\right)_{2}$ (b) for 72 hours. The proliferation was measured by $\left[{ }^{3} \mathrm{H}\right]$ thymidine incorporation. Bars show the mean $\pm \mathrm{SD}$ ( $n=8$ per group). B cells from PPAR $\gamma^{+/-}$mice (+/-) demonstrated a significantly stronger response to LPS or anti-mouse $\operatorname{lgM~} \mathrm{F}\left(\mathrm{ab}^{\prime}\right)_{2}$ compared with the cells from wild-type littermates $(+/+)$. Statistical analysis using data from all mice as well as every littermate group gave a significant difference. 
Table 1

Basal proliferative level and stimulation index of B cells from PPAR $\gamma^{+/-}$or $\mathrm{PPAR} \gamma^{+/+}$mice

\begin{tabular}{cccccc}
\hline \multicolumn{2}{c}{$\begin{array}{c}\text { Basal proliferative } \\
\text { level }(\mathrm{cpm})\end{array}$} & SI & $\mathrm{cpm}$ & \multicolumn{2}{c}{ LPM F $\left(\mathrm{ab}^{\prime}\right) 2$} \\
$\mathrm{PPAR}^{+/-}$ & $440 \pm 123$ & $264 \pm 88.8$ & $1,070,505 \pm 16,350$ & $76.3 \pm 39.2$ & $31,323 \pm 19,111$ \\
${\text { PPAR } \gamma^{++}}^{++}$ & $242 \pm 85.4^{\mathrm{A}}$ & $129 \pm 62.3^{\mathrm{A}}$ & $32,924 \pm 20,137^{\mathrm{A}}$ & $48.4 \pm 17.1^{\mathrm{B}}$ & $11,228 \pm 5,865^{\mathrm{B}}$
\end{tabular}

B cell proliferation by thymidine incorporation was determined after 72 hours of incubation, as described in Methods. The results are expressed as mean $\pm \mathrm{SD}(n=10)$. ${ }^{\mathrm{A}} P<0.01 ;{ }^{\mathrm{B}} P<0.05$.

termate group $(P<0.05)$. Although the SI did not differ significantly in B cells stimulated with $B$ cell receptor cross-linking from a littermate group, the SI of B cells stimulated with antimouse $\operatorname{IgM~} \mathrm{F}\left(\mathrm{ab}^{\prime}\right)_{2}$ from the other littermate group, as well as the

No significant difference was observed between the proliferation of naive $T$ cells from PPAR $\gamma^{+/}$mice and that from wild-type littermate mice (Figure 1). Although the variance between individual mice is rather high, partly due to the heterogeneous genetic background of ICR mice, there was no statistical difference. This result suggests that the reduced amount of PPAR $\gamma$ does not affect the proliferative response of naive $\mathrm{T}$ cells.

$B$ cells from PPAR $\gamma^{1-}$ mice proliferate vigorously upon stimulation. Next, we investigated the $\mathrm{B}$ cell proliferative response. Naive B cells purified from both types of unimmunized mice were stimulated with either LPS or anti-mouse IgM F $\left(\mathrm{ab}^{\prime}\right)_{2}$. B cells from PPAR $\gamma^{+/-}$mice showed a remarkably exaggerated response to each stimulus compared with B cells from wild-type littermates (Figure 2, $a$ and $b$ ). To decrease the influence of genetic heterogeneity of ICR mice, we compared PPAR $\gamma^{+/-}$and PPAR $\gamma^{+/+}$littermates from the same litter. A statistical analysis using the littermates as well as the whole sample gave a significant difference $(P<0.01$ in the case of LPS stimulation and $P<0.05$ in the case of $\mathrm{B}$ cell receptor cross-linking). Since the basal proliferative response of $\mathrm{B}$ cells from PPAR $\gamma^{+/}$mice was significantly higher than PPAR $\gamma^{+/}$mice $(242 \pm 85.4 \mathrm{cpm}$ in $\mathrm{PPAR} \gamma^{+/}$and $440 \pm 123 \mathrm{cpm}$ in PPAR $\left.\gamma^{+/}\right)$, we analyzed stimulation index (SI) of the B cell response to exclude the possibility that the higher response after stimulation simply reflects the basal proliferative level. As summarized in Table 1, the SI of LPS-stimulated B cells from PPAR $\gamma^{+/-}$mice was significantly higher in each lit- whole sample, showed significant differences $(P<0.05$ in the case of a littermate analysis as well as the whole sample). These results suggest that B cells from PPAR $\gamma^{+/-}$mice are intrinsically abnormal.

The PPAR $\gamma$ agonists are not cytotoxic for $B$ cells from $P P A R \gamma^{\dagger /}$ and PPAR $\gamma^{\dagger+}$ mice. To confirm that this different trait of B cells from PPAR $\gamma^{+/}$mice depends on PPAR $\gamma$ haploinsufficiency, we studied whether PPAR $\gamma$ activation is involved in B cell function. The B cell proliferative response induced by either LPS or anti-mouse $\operatorname{IgM~F}\left(\mathrm{ab}^{\prime}\right)_{2}$ was suppressed by all PPAR $\gamma$ agonists tested, including $15 \mathrm{~d}-\mathrm{PGJ}_{2}$, troglitazone, pioglitazone, and rosiglitazone (BRL49653) (Figure 3, a and b). The degree of inhibition depended on the dose of the agonist. The enhanced proliferative response of B cells from PPAR $\gamma^{+/-}$mice was also suppressed by the PPAR $\gamma$ agonists. Interestingly, a higher dose was required to achieve almost the same degree of suppression of B cell proliferation from $\mathrm{PPAR} \gamma^{+/-}$mice as for the wild-type.

Since Padilla et al. demonstrated that PPAR $\gamma$ agonists induce apoptosis in normal as well as malignant B-lineage cells (13), we examined the cell viability to examine the possibility that suppressive activity of the PPAR $\gamma$ agonists is due to their cytotoxic effect. In both $\mathrm{PPAR}^{+/+}$and PPAR $\gamma^{+/-}$mice the B cell viability was not significantly altered by the presence of either $20 \mu \mathrm{M}$ or $50 \mu \mathrm{M}$ of troglitazone or $2 \mu \mathrm{M}$ of $15 \mathrm{~d}-\mathrm{PGJ}_{2}$, whereas the viable cell count decreased significantly at $5 \mu \mathrm{M}$ of $15 \mathrm{~d}-$ $\mathrm{PGJ}_{2}$ (Figure 4, $\mathrm{a}$ and $\mathrm{b}$ ). The other TZDs (pioglitazone and rosiglitazone) did not alter the cell viability as well

\section{Figure 3}

PPAR $\gamma$ agonistic ligands suppress the proliferation of naive $B$ cells from both PPAR $\gamma^{+-}$and $\mathrm{PPAR}^{+/+}$mice stimulated with LPS or anti-mouse $\operatorname{lgM} \mathrm{F}\left(\mathrm{ab}^{\prime}\right)_{2}$. B cells $\left(10^{5}\right)$ purified from spleens were stimulated with $10 \mu \mathrm{g} / \mathrm{ml}$ of LPS (a) or $20 \mu \mathrm{g} / \mathrm{ml}$ of anti-mouse IgM $\mathrm{F}\left(\mathrm{ab} \mathrm{b}^{\prime}\right)_{2}$ (b) for 72 hours in the absence or presence of PPAR $\gamma$ agonistic ligands at various concentrations (TZDs: 20, $50 \mu \mathrm{M} ; 15 \mathrm{~d}-\mathrm{PGJ}_{2}$ : 2, $5 \mu \mathrm{M})$. Proliferation was measured by $\left[{ }^{3} \mathrm{H}\right]$ thymidine incorporation. Bars show the mean $\pm \mathrm{SD}$ ( $n=10$ per group). All of the tested PPAR $\gamma$ agonistic ligands $\left(15 \mathrm{~d}-\mathrm{PG} \mathrm{J}_{2}\right.$, troglitasone, pioglitasone, and rosiglitasone) demonstrated suppressive activity. Data from every littermate group were analyzed statistically using paired $t$ test.

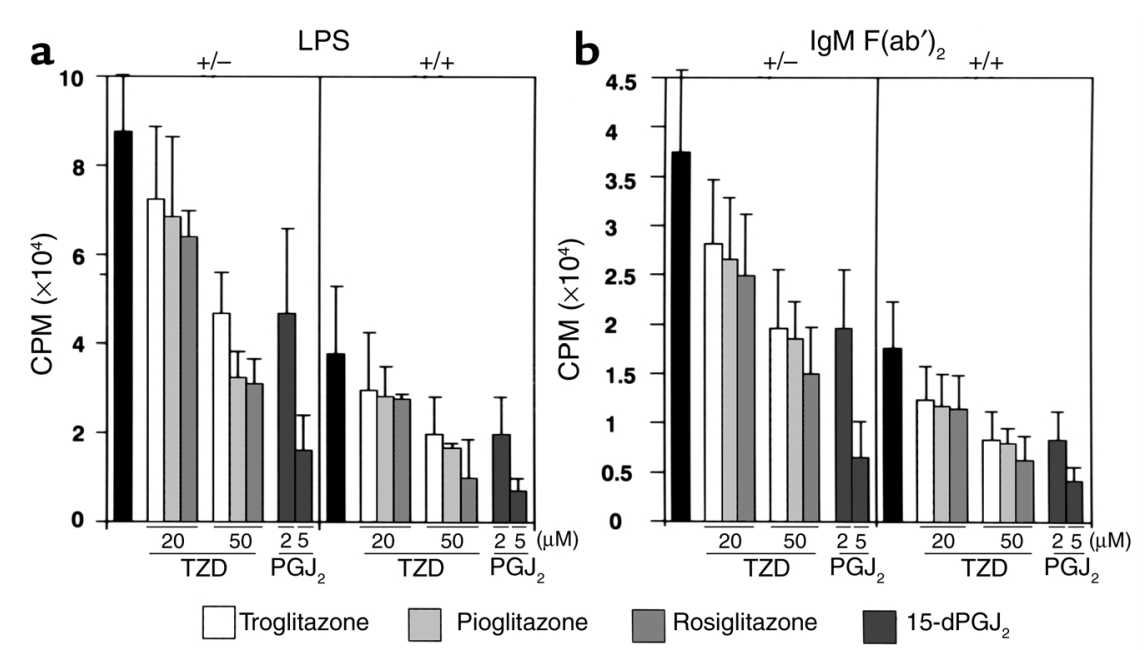



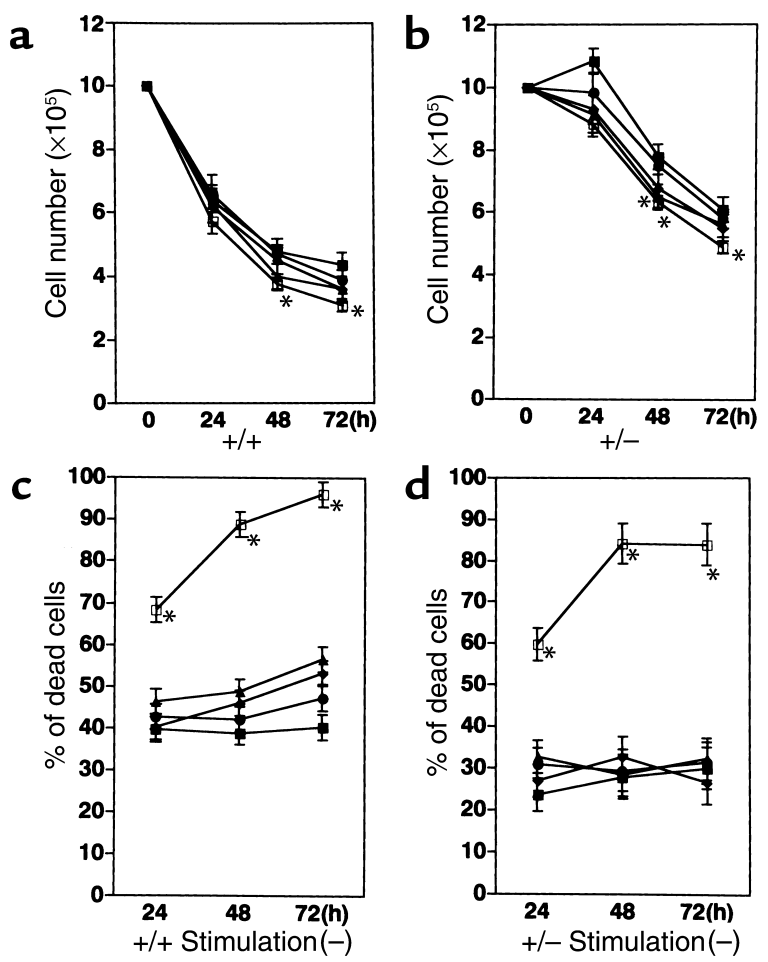

Figure 4

The cell viability as well as the proportion of dead/dying cells are different between PPAR $\gamma^{+/+}$and PPAR $\gamma^{+/}$mice, whereas the addition of PPAR $\gamma$ agonists did not alter those parameters, except $5 \mu \mathrm{M}$ of $15 \mathrm{~d}-\mathrm{PG} \mathrm{J}_{2}$. The $\mathrm{B}$ cells from PPAR $\gamma^{+/+}(\mathbf{a})$ or $\operatorname{PPAR} \gamma^{+/-}(\mathbf{b})$ are cultured in the absence or presence of PPAR $\gamma$ agonists and their viable cell number were counted by trypan blue exclusion. The percentage of dead or dying cells of B cells from PPAR $\gamma^{+/}(\mathbf{c})$ or PPAR $\gamma^{+/}(\mathbf{d})$ in the culture were counted by PI staining. B cells were cultured without agonist (closed squares), or with troglitazone $20 \mu \mathrm{M}$ (filled circles), troglitazone $50 \mu \mathrm{M}$ (filled triangles), $15 \mathrm{~d}-\mathrm{PG} \mathrm{J}_{2} 2 \mu \mathrm{M}$ (filled diamonds), and $15 \mathrm{~d}-\mathrm{PG})_{2} 5 \mu \mathrm{M}$ (open squares). ${ }^{*} P<0.05$ for the cell number or percentage of dead cells compared to those in the absence of the agonist.

(data not shown). Although it seems that the proportion of dead cells assayed by PI staining gradually increased during the culture in the presence of PPAR $\gamma$ agonists (see Figure 4c), a no significant difference was observed in the ratio of dead cells except $5 \mu \mathrm{M}$ of $15 \mathrm{~d}-$ $\mathrm{PGJ}_{2}$, which induced massive cell death in $\mathrm{B}$ cells from both PPAR $\gamma^{+/+}$and PPAR $\gamma^{+/-}$mice (Figure 4, c and d). These results indicate that at the concentrations we used PPAR $\gamma$ agonists are not cytotoxic except $5 \mu \mathrm{M}$ of $15 \mathrm{~d}-\mathrm{PGJ}_{2}$ and that they counteract the proliferative response, although it is true that PPAR $\gamma$ agonists at rather higher concentration can induce cell death. The reason for this partial inconsistency regarding the concentration of PPAR $\gamma$ agonists that induce cell death between our data and the previous report might be that we used B cells from a different strain; we used B cells from ICR mice while Padilla et al. used BDF1 mice.

The increased viability of $B$ cells from PPAR $\gamma^{1 /-}$ mice. Interestingly, a dramatic difference was observed in the viability of $\mathrm{B}$ cells from PPAR $\gamma^{+/+}$versus PPAR $\gamma^{+/-}$mice irre- spective of the absence or presence of PPAR $\gamma$ agonists (a significant difference, $P<0.01$, was observed in the cell number over all time points). Since the cell number of PPAR $\gamma^{+/}$increased slightly at the 24-hour point, the increased basal proliferative response might contribute in the increased cell viability. The counting of dead cells revealed that B cells from PPAR $\gamma^{+/}$mice are less susceptible to cell death, since the proportion of dead cells is around $40 \%$ in PPAR $\gamma^{++} \mathrm{B}$ cells and $25 \%$ in PPAR $\gamma^{+/}$ $\mathrm{B}$ cells, respectively, in the absence of the agonists (compare Figure 4, $c$ and d). The activation of $B$ cells with either LPS or $\operatorname{IgM~} \mathrm{F}\left(\mathrm{ab}^{\prime}\right)_{2}$ stimuli did not alter the ratio of dead cells in B cells from both mice (data not shown). The increased cell survival might contribute in the increased thymidine incorporation of PPAR $\gamma^{+/-} \mathrm{B}$ cells. Taken together, these results indicate the involvement of PPAR $\gamma$ in the B cell proliferative response and that the reduced amount of PPAR $\gamma$ results in a hyperproliferative response of $\mathrm{B}$ cells.

Spontaneous activation of NF- $K B$ in $B$ cells of PPAR $\gamma^{+-}$ mice. To investigate the mechanism of hyperreactivity in B cells from the mutant mice, we examined nuclear translocation of NF- $\mathrm{KB}$, which is proposed to be regulated by $\operatorname{PPAR} \gamma(7,8)$. Nuclear extracts of $B$ cells from PPAR $\gamma^{+/}$mice that were stimulated with LPS exhibited more enhanced binding activity to NF- $\mathrm{KB}$ oligonucleotides in EMSA (Figure 5a). Strikingly, NF-KB activity was observed even in the resting $\mathrm{B}$ cells without stimulation in PPAR $\gamma^{+/-}$mice. The activation of NF- $\kappa B$ is associated with phosphorylation of IKB, followed by
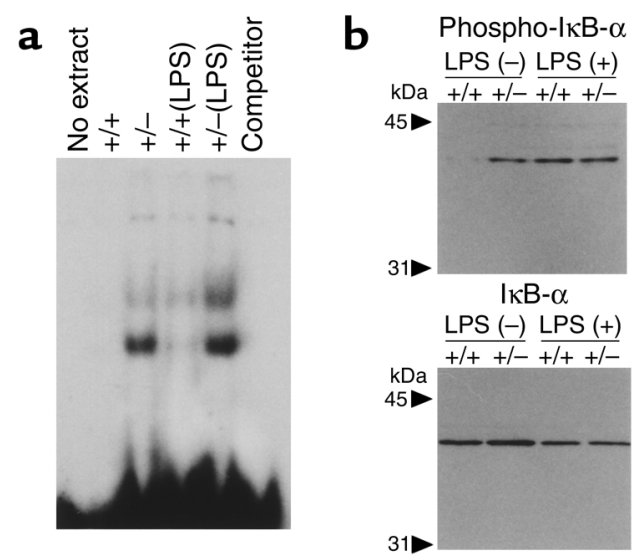

\section{Figure 5}

Activation of NF- $\kappa$ B pathway in B cells from PPAR $\gamma^{+/-}$mice. (a) Nuclear extracts from $B$ cells were analyzed by EMSA for the ability to bind to an NF-KB consensus probe. Lane 1: No extract, with labeled oligonucleotide; lane 2: resting $B$ cells from wild-type mice $(+/+)$; lane 3: resting B cells from PPAR $\gamma^{+/-}$mice (+/-); lane 4: stimulated $B$ cells by LPS for 5 minutes from wild-type mice; lane 5 : stimulated B cells from PPAR $\gamma^{+/-}$mice; lane 6 : lane 5 with excess of cold oligonucleotide; lane 7: lane 5 without labeled oligonucleotide. (b) Phosphorylation of I $\mathrm{K} B \alpha$. Cell lysates from $B$ cells were probed with anti-phosphorylated $I \kappa B \alpha$ (lanes 1-4) and anti- I $\mathrm{KB} \alpha$ (lanes 5-8). Lanes 1 and 5 were resting $B$ cells from wild-type mice. Lanes 2 and 6 were resting $B$ cells from PPAR $\gamma^{+/-}$mice. Lanes 3 and lane 7 were $B$ cells from wild-type mice, stimulated with LPS for 5 minutes. Lanes 4 and 8 were stimulated $B$ cells from PPAR $\gamma^{+/-}$mice. 

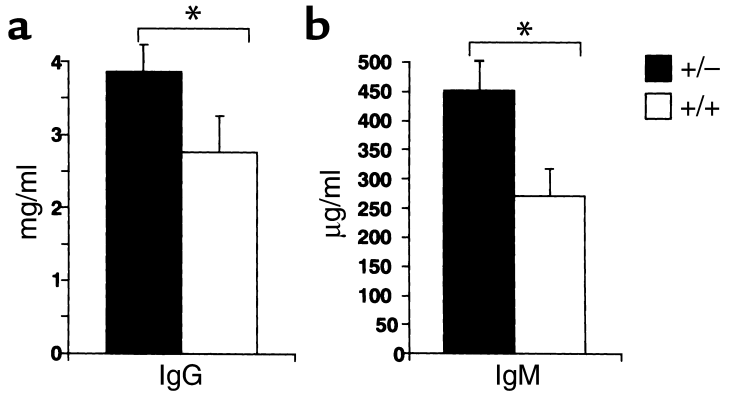

Figure 6

Serum IgG and IgM levels were increased in PPAR $\gamma^{+/-}$mice. Serum $\operatorname{IgG}(\mathbf{a})$ and IgM (b) levels in PPAR $\gamma^{+/-}$mice (closed column, +/-) were higher than in wild-type mice (open column, $+/+$ ). Both PPAR $\gamma^{+/}$and wild-type 12-week-old mice were bled, and serum IgG and IgM levels were measured by ELISA. The mean Ab titers ( \pm SD) of each group of ten mice are shown. The statistical differences between PPAR $\gamma^{+/-}$and PPAR $\gamma^{+/+}$littermates derived from the same litter were significant $\left({ }^{*} P<0.01\right)$.

degradation of I $\mathrm{KB}$ by the proteasome and nuclear translocation of NF- $\mathrm{KB}(35)$. Therefore, in order to investigate the mechanism of NF- $\mathrm{KB}$ activation, we examined the phosphorylation of $I \kappa B \alpha$ in B cells. While the total amount of $I \kappa B \alpha$ was not significantly altered, immunoblotting revealed that the phosphorylated form of $I \kappa B \alpha$ increased in B cells from unprimed PPAR $\gamma^{+-}$mice (Figure $5 \mathrm{~b}$ ). These results indicate that in the mutants NF- $\mathrm{KB}$ was spontaneously activated without addition of any stimulus.

A significant increase in the serum Ig level was observed in the unprimed PPAR $\gamma^{+/-}$mice (Figure 6). These results indicate that $\mathrm{B}$ cells from PPAR $\gamma^{+/-}$mice are spontaneously activated.

Antigen-specific immune response is enhanced in PPAR $\gamma$ haploinsufficient mice. $\mathrm{B}$ cells differentiate into Ab-producing cells by $T$ cell help. Ab enhances antigen-presentation of the immune system by facilitating antigen uptake by forming immune complex. Conversely, B cells are valuable antigen-presenting cells for circulating antigens that are ingested into $B$ cells via their antigen-specific receptor (36). Thus, B cells contribute to efficient generation of antigen-specific immune responses. Therefore, we examined whether the antigen-specific immune response is altered in PPAR $\gamma^{+/}$.

Splenocytes from PPAR $\gamma^{+-}$immunized with either OVA or mBSA demonstrated an enhanced antigen-specific immune response against the immunized antigen (Figure 7, $a$ and $c$ ). The level of $A b$ against either OVA or mBSA in the sera from the immunized mice was also significantly increased in PPAR $\gamma^{+/}$mice (Figure 7, b and $\mathrm{d}$ ). These results indicate that the antigen-specific immune response is probably enhanced due to $\mathrm{B}$ cell hyperreactivity in PPAR $\gamma^{+/}$mice.

The production of T cell-derived cytokines was also enhanced, since higher amounts of both IL-2 and IFN- $\gamma$ were detected in the supernatant of antigenstimulated splenocytes from PPAR $\gamma^{+-}$mice in comparison with the wild-type littermate mice (our unpublished observation). However, we could not evaluate deviation toward a Th1 response, since IL-4 in the supernatant was below the detectable level from either the mutant or control mice and since no significant difference in the amount of Ig isotypes in the sera was noted (data not shown). We also could not discern whether the enhanced total production of cytokines in the supernatant is due to the increased production by each antigen-specific $\mathrm{T}$ cell or simply reflects the increased frequency of antigen-specific $T$ cells generated by the enhanced response.

PPAR $\gamma^{+-}$mice developed more severe antigen-induced arthritis. B cell hyperreactivity is proposed to be involved in the pathogenesis of autoimmune diseases, including RA. Therefore, to explore the association of B cell
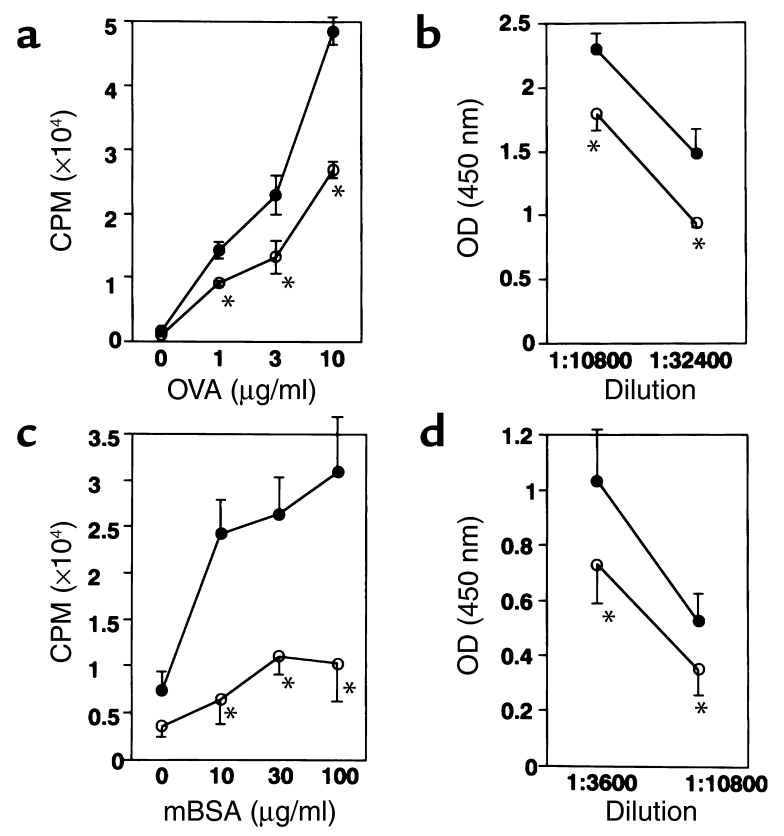

\section{Figure 7}

Antigen-specific immune response was enhanced in PPAR $\gamma^{+/-}$mice. (a) Proliferation of splenocytes from wild-type mice (open circles, $+/+$ ) and PPAR $\gamma^{+/-}$mice (filled circles, +/-), both of which were primed with OVA. Proliferation was measured by $\left[{ }^{3} \mathrm{H}\right]$ thymidine incorporation in the presence of various concentrations of OVA. Bars show the mean \pm SD $(n=10$ per group). The difference between the two groups was significant $\left({ }^{*} P<0.01\right)$. (b) The level of $A b$ against OVA in sera from mice primed with OVA. Mice were bled 30 days after priming with OVA and assayed for the anti-OVA Ab level by ELISA. The mean Ab titers ( \pm SD) of each group of ten mice are shown. The difference between the two groups was significant $\left({ }^{*} P<0.01\right)$. (c) Proliferation against mBSA of splenocytes from mBSA-primed wild-type control mice (open circles, $+/+$ ) and PPAR $\gamma^{+/-}$mice (filled circles, $+/-$), respectively. Proliferation was measured by $\left[{ }^{3} \mathrm{H}\right]$ thymidine incorporation in the presence of various concentrations of mBSA. Bars show the mean \pm SD $(n=10$ per group).The difference between the two groups was significant $\left({ }^{*} P<0.001\right)$. (d) Mice were bled 30 days after intra-articular challenge with mBSA and assayed for the anti-mBSA Ab level by ELISA. The mean $A b$ titers $( \pm S D)$ of each group of the total ten mice are shown. The statistical difference between PPAR $\gamma^{+/-}$and PPAR $\gamma^{+/+}$littermates derived from the same litter were significant $\left({ }^{*} P<0.01\right)$. 


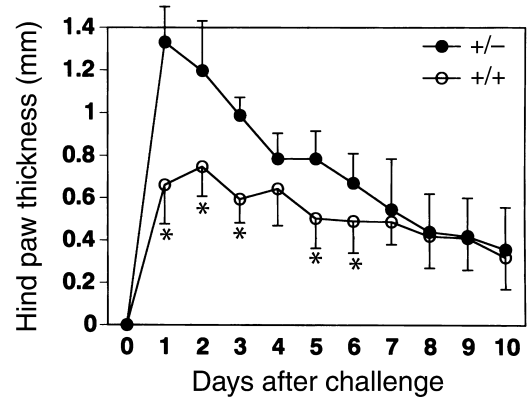

Figure 8

PPAR $\gamma^{+/-}$mice showed more severe antigen-induced arthritis. Mice primed with $\mathrm{mBSA}$ were challenged intra-articularly with the antigen on day 0 . The increase in hind paw thickness during the course of the disease was monitored using a dial-gauge calipers. Bars show the mean $\pm \operatorname{SD}\left(n=10\right.$ per group). The statistical difference $\left({ }^{*} P<0.01\right)$ between the PPAR $\gamma^{+/-}$and PPAR $\gamma^{+/+}$mice from day 1 to day 5 was calculated using data of all mice as well as every littermate group.

hyperreactivity in $\mathrm{PPAR} \gamma^{+/}$with the disease, we employed an antigen-induced arthritis model and evaluated the arthritis severity in terms of the ankle joint thickness. In the wild-type littermate mice used as a control, the maximal increase of joint thickness was almost $0.8 \mathrm{~mm}$ at $24-48$ hours after the antigen challenge, and it began to decline thereafter. By day 10, only slight joint swelling remained. In contrast, in PPAR $\gamma^{+/-}$ mice, more severe arthritis was induced: the maximal increase of joint thickness was more than $1.3 \mathrm{~mm}$ at 24 hours after the challenge (Figure 8). Although joint swelling in the PPAR $\gamma^{+/}$mice started earlier than in the control, arthritis in the PPAR $\gamma^{+/-}$mice was not prolonged, and on day 8 it was almost the same as in the wild-type controls. Histological examination of the ankle joints revealed synovial lining cell hyperplasia, fibrin deposits, and formation of pannus-like tissues (Figure 9). Hyperplasia of synovial lining cells was accompanied by the accumulation of numerous mononuclear cells filled into tarsal-tibial joint space, which was more vigorous in $\mathrm{PPAR} \gamma^{+/}$than $\mathrm{PPAR} \gamma^{+/+}$ mice. A greater number of inflammatory cells also invaded into periarticular soft tissues in PPAR $\gamma^{+/}$than in PPAR $\gamma^{+/+}$mice. Thus, the histological change was more severe in PPAR $\gamma^{+/-}$than in PPAR $\gamma^{+/+}$mice.

Taken together, these findings indicate that PPAR $\gamma$ haploinsufficiency results in dysregulation of NF- $\kappa B$ and hyperreactivity of $B$ cells. The reduced expression of PPAR $\gamma$ in physiological level affects B cells more profoundly than $T$ cells. The hyperreactivity of $B$ cells might be related to the exacerbation of arthritis in PPAR $\gamma^{+/-}$mice.

\section{Discussion}

In the present study, we showed that PPAR $\gamma$ haploinsufficiency affects the $\mathrm{B}$ cell proliferative response. The increased $\mathrm{B}$ cell proliferative response may be involved in the enhanced antigen-specific immune response, which contributes to the exacerbation of antigen- induced arthritis. We conclude that the enhanced immune response in PPAR $\gamma^{+/}$mice is attributable, at least in part, to hyperreactivity of B cells. Our reasoning is discussed below.

$\mathrm{B}$ cells from PPAR $\gamma^{+/-}$mice expand more rapidly and more aggressively in response to proliferative stimuli. Therefore, during immunization, the frequency of $\mathrm{B}$ cells specific for the antigen should increase. The increased number of antigen-specific B cells enhances the $T$ cell response specific for the antigen via antigenpresentation by $\mathrm{B}$ cells. Conversely, the increased number of antigen-specific $\mathrm{T}$ cells promotes clonal expansion of antigen-specific $B$ cells and vice versa. Thus, hyperreactivity of $\mathrm{B}$ cells should be a positive driving force for the antigen-specific immune response.

This assumption could be confirmed by adoptive transfer experiments or in vitro reconstitution assays using B cells from PPAR $\gamma^{+/}$mice and antigen-specific $\mathrm{T}$ cells from wild-type mice. However, the heterogeneous genetic background, especially regarding MHC, of ICR mice that we employed in this study does not allow these kinds of experiments.

The genetic heterogeneity of ICR mice also prevented us from examining antigen-presentation including MHC class II expression. This point is important since not only B cells but also other types of cells, including macrophages and synoviocytes, are involved in antigen presentation. Since their function is known to be altered by PPAR $\gamma$ agonists, it is possible that other cell types also contribute in enhancement of antigen-spe-
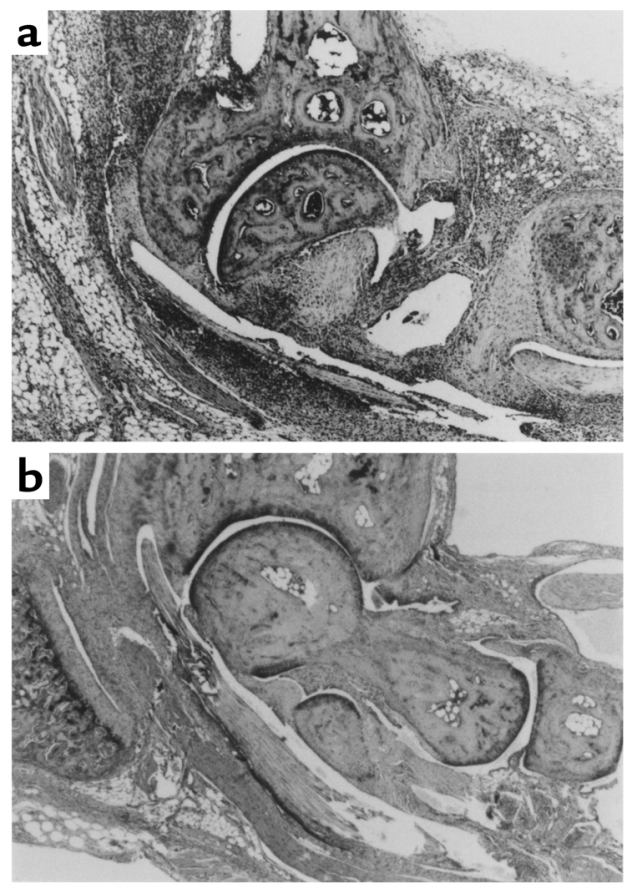

Figure 9

Histological examination of ankles from arthritic mice. Hematoxylin and eosin staining of the ankle joint revealed increased infiltration of inflammatory mononuclear cells in PPAR $\gamma^{+/-}$mice (a) compared with wild-type mice (b). 
cific immune response and arthritis, via modification of the antigen-presentation or inflammatory process. The increased cell viability could contribute in the increased thymidine incorporation of $\mathrm{B}$ cells from $\mathrm{PPAR}^{+/-}$mice, since the increased thymidine incorporation depends on both the number of cell cycle that each cell undergoes and the number of cells that undergo mitosis. Nevertheless, since the increased basal proliferative response reflects the increased viability in addition to the increased proliferation, the increase of SI, which takes into account the increased basal proliferation in B cells from PPAR $\gamma^{+/}$mice, strongly suggest the hyperproliferative response of the B cells. In addition, although PI staining does not distinguish apoptosis-caused cell death from necrosis-induced cell death (33), it is possible that haploinsufficiency of PPAR $\gamma$ render B cells less susceptible to apoptosis. It would be interesting to examine whether the haploinsufficiency of PPAR $\gamma$ is related to prevention of apoptosis.

Toll-like receptor 4 stimulated with LPS is known to involve the NF-KB pathway via MyD88/IRAK $(37,38)$. Signaling via $\mathrm{B}$ cell antigen receptor cross-linking is also involved in NF-kB (39). It is well known that PPAR $\gamma$ agonistic ligands negatively regulate macrophage activation through transcriptional suppression via NF- $\mathrm{\kappa B}, \mathrm{AP}-1$, and STAT $(7,8)$, although a recent paper demonstrated a PPAR $\gamma$-independent antiinflammatory effect of PPAR $\gamma$ agonistic ligands (18). These findings support our idea that hyperreactivity of $\mathrm{B}$ cells can be explained at least by activation of NF- $\mathrm{KB}$, which should be regulated by PPAR $\gamma$. However, the exact mechanism of NF- $\kappa B$ pathway suppression by PPAR $\gamma$ remains unknown. A direct interaction between NF- $\mathrm{NB}$ and PPAR $\gamma$ has been reported (40). PPAR $\alpha$, another PPAR isotype, was reported to suppress the NF- $\kappa B$ pathway by increasing the expression of $I \kappa B \alpha$ (41). Since we found that phosphorylation of $I \kappa B \alpha$ is accelerated in the mutant while the total amount of $\mathrm{I} \kappa \mathrm{B} \alpha$ does not differ significantly, it is possible that PPAR $\gamma$ regulates upstream of I $\mathrm{B} \alpha$, such as IKK in B cells. Alternatively, the haploinsufficiency of PPAR $\gamma$ might cause suppression of other regulatory molecules.

$\mathrm{NF}-\mathrm{KB}$ is also indispensable for $\mathrm{T}$ cell proliferation (42). PKC- $\theta$ is located upstream of the NF- $\mathrm{KB}$ pathway. The reason why the phenotype is affected in $\mathrm{B}$ cells but not in $T$ cells is unclear. It is possible that regulation of NF- $\kappa B$ by PPAR $\gamma$ is redundant or dispensable in T cells.

It is known that $\mathrm{B}$ cell hyperreactivity is one of the characteristics of autoimmune disease patients. An elevated titer of immunoglobulins, an enhanced proliferative response to various stimuli, and reduced susceptibility to apoptosis were reported (43-45). Therefore, our findings that PPAR- $\gamma$ haploinsufficiency especially affects $B$ cell reactivity provide new insight into the association between PPAR- $\gamma$ and immunological disease.

\section{Acknowledgments}

We are grateful to Naoko Sato, Kazumi Abe, and Atumi Ohkubo for their excellent technical assistance. This work was supported by grants from the Ministry of Health, Labor and Welfare, and Grant-in-Aid for Scientific Research from the Ministry of Education, Culture, Sports, Science and Technology of Japan.

1. Tontonoz, P., Hu, E., and Spiegelman, B.M. 1994. Stimulation of adipogenesis in fibroblasts by PPAR gamma 2, a lipid-activated transcription factor. Cell. 79:1147-1156.

2. Kliewer, S.A., et al. 1994. Differential expression and activation of a family of murine peroxisome proliferator-activated receptors. Proc. Natl. Acad. Sci. USA. 91:7355-7359.

3. Forman, B.M., et al. 1995. 15-Deoxy-delta 12,14-prostaglandin J2 is a ligand for the adipocyte determination factor PPAR gamma. Cell. 83:803-812.

4. Kliewer, S.A., et al. 1995. A prostaglandin J2 metabolite binds peroxisome proliferator-activated receptor gamma and promotes adipocyte differentiation. Cell. 83:813-819.

5. Lemberger, T., Desvergne, B., and Wahli, W. 1996. Peroxisome proliferator-activated receptors: a nuclear receptor signaling pathway in lipid physiology. Annu. Rev. Cell. Dev. Biol. 12:335-363.

6. Kersten, S., Desvergne, B., and Wahli, W. 2000. Roles of PPARs in health and disease. Nature. 405:421-424.

7. Ricote, M., Li, A.C., Willson, T.M., Kelly, C.J., and Glass, C.K. 1998. The peroxisome proliferator-activated receptor-gamma is a negative regulator of macrophage activation. Nature. 391:79-82.

8. Jiang, C., Ting, A.T., and Seed, B. 1998. PPAR-gamma agonists inhibit production of monocyte inflammatory cytokines. Nature. 391:82-86.

9. Clark, R.B., et al. 2000. The nuclear receptor PPAR gamma and immunoregulation: PPAR gamma mediates inhibition of helper $\mathrm{T}$ cell responses. J. Immunol. 164:1364-1371.

10. Harris, S.G., and Phipps, R.P. 2000. Peroxisome proliferator-activated receptor gamma (PPAR-gamma) activation in naive mouse $\mathrm{T}$ cells induces cell death. Ann. N. Y. Acad. Sci. 905:297-300.

11. Yang, X.Y., et al. 2000. Activation of human T lymphocytes is inhibited by peroxisome proliferator-activated receptor gamma (PPARgamma) agonists. PPARgamma co-association with transcription factor NFAT. J. Biol. Chem. 275:4541-4544.

12. Padilla, J., Kaur, K., Harris, S.G., and Phipps, R.P. 2000. PPAR-gammamediated regulation of normal and malignant B lineage cells. Ann. N. Y. Acad. Sci. 905:97-109.

13. Padilla, J., Kaur, K., Cao, H.J., Smith, T.J., and Phipps, R.P. 2000. Peroxisome proliferator activator receptor-gamma agonists and 15-deoxyDelta $(12,14)(12,14)-P G J(2)$ induce apoptosis in normal and malignant B-lineage cells. J. Immunol. 165:6941-6948.

14. Lehmann, J.M., et al. 1995. An antidiabetic thiazolidinedione is a high affinity ligand for peroxisome proliferator-activated receptor gamma (PPAR gamma). J. Biol. Chem. 270:12953-12956.

15. Nolte, R.T., et al. 1998. Ligand binding and co-activator assembly of the peroxisome proliferator-activated receptor-gamma. Nature. 395:137-143

16. Straus, D.S., et al. 2000. 15-deoxy-delta 12,14-prostaglandin J2 inhibits multiple steps in the NF-kappa B signaling pathway. Proc. Natl. Acad. Sci. USA. 97:4844-4849.

17. Rossi, A., et al. 2000. Anti-inflammatory cyclopentenone prostaglandins are direct inhibitors of IkappaB kinase. Nature. 403:103-108.

18. Chawla, A., et al. 2001. PPAR-gamma dependent and independent effects on macrophage-gene expression in lipid metabolism and inflammation. Nat. Med. 7:48-52.

19. Hale, L.P., and Haynes, B.F. 2001. Pathology of rheumatoid arthritis and associated disorders. In Arthritis and allied conditions. A textbook of rheumatology. 14th edition. Volume 1. W.J. Koopman, editor. Williams \& Wilkins Press. Baltimore, Maryland, USA. 1103-1127.

20. Weyand, C.M., and Goronzy, J.J. 1997. Pathogenesis of rheumatoid arthritis. Med. Clin. North. Am. 81:29-55.

21. Misaki, Y., Ezaki, I., and Yamamoto, K. 1998. T cell clonality in the rheumatic diseases. APLAR Journal of Rheumatology. 1:194-197.

22. Carson, D.A., et al. 1987. Rheumatoid factor and immune networks. Annu. Rev. Immunol. 5:109-126.

23. Kawahito, Y., et al. 2000. 15-deoxy-delta(12,14)- PGJ(2) induces synoviocyte apoptosis and suppresses adjuvant-induced arthritis in rats. $J$. Clin. Invest. 106:189-197.

24. Kubota, N., et al. 1999. PPAR gamma mediates high-fat diet-induced adipocyte hypertrophy and insulin resistance. Mol. Cell. 4:597-609.

25. Kadowaki, T. 2000. Insights into insulin resistance and type 2 diabetes from knockout mouse models. J. Clin. Invest. 106:459-465.

26. Barak, Y., et al. 1999. PPAR gamma is required for placental, cardiac, and adipose tissue development. Mol. Cell. 4:585-595.

27. Rosen, E.D., et al. 1999. PPAR gamma is required for the differentiation of adipose tissue in vivo and in vitro. Mol. Cell. 4:611-617. 
28. Kawahata, K., et al. 1999. Altered expression level of a systemic nuclear autoantigen determines the fate of immune response to self. J. Immunol. 162:6482-6491.

29. Setoguchi, K., et al. 2000. Antigen-specific T cells transduced with IL10 ameliorate experimentally induced arthritis without impairing the systemic immune response to the antigen. J. Immunol. 165:5980-5986.

30. Li, L., Yee, C., and Beavo, J.A. 1999. CD3- and CD28-dependent induction of PDE7 required for T cell activation. Science. 283:848-851.

31. Takai, T., Li, M., Sylvestre, D., Clynes, R., and Ravetch, J.V. 1994. FcR gamma chain deletion results in pleiotrophic effector cell defects. Cell. 76:519-529.

32. Nicoletti, I., Migliorati, G., Pagliacci, M. C., Grignani, F., and Riccardi, C. 1991. A rapid and simple method for measuring thymocyte apoptosis by propidium iodide staining and flow cytometry. J Immunol Methods. 139:271-279.

33. Hu, X., Tang, M., Fisher, A.B., Olashaw, N., and Zuckerman, K.S. 1999. TNF-alpha-induced growth suppression of CD34+ myeloid leukemic cell lines signals through TNF receptor type I and is associated with NFkappa B activation. J. Immunol. 163:3106-3115.

34. Liou, H.C., Sha, W.C., Scott, M.L., and Baltimore, D. 1994. Sequentia induction of NF-kappa B/Rel family proteins during B-cell terminal differentiation. Mol. Cell. Biol. 14:5349-5359.

35. Karin, M., and Ben-Neriah, Y. 2000. Phosphorylation meets ubiquitination: the control of NF-kappa B activity. Annu. Rev. Immunol. 18:621-663.

36. Lanzavecchia, A. 1990. Receptor-mediated antigen uptake and its effect on antigen presentation to class II-restricted T lymphocytes. Annu.
Rev. Immunol. 8:773-793.

37. Aderem, A., and Ulevitch, R.J. 2000. Toll-like receptors in the induction of the innate immune response. Nature. 406:782-787.

38. Zhang, G., and Ghosh, S. 2001. Toll-like receptor-mediated NF- $\mathrm{BB}$ activation: a phylogenetically conserved paradigm in innate immunity. $J$. Clin. Invest. 107:13-19.

39. Reth, M., and Wienands, J. 1997. Initiation and processing of signals from the B cell antigen receptor. Annu. Rev. Immunol. 15:453-479.

40. Chung, S.W., et al. 2000. Oxidized low density lipoprotein inhibits interleukin-12 production in lipopolysaccharide-activated mouse macrophages via direct interactions between peroxisome proliferatoractivated receptor-gamma and nuclear factor-kappa B. J. Biol. Chem. 275:32681-32687.

41. Delerive, P., Gervois, P., Fruchart, J.C., and Staels, B. 2000. Induction of $\mathrm{I} \kappa \mathrm{B} \alpha$ expression as a mechanism contributing to the anti-inflammatory activities of peroxisome proliferator-activated receptor-alpha activators. J. Biol. Chem. 75:36703-36707.

42. Sun, Z., et al. 2000. PKC-theta is required for TCR-induced NF-kappaB activation in mature but not immature $\mathrm{T}$ lymphocytes. Nature. 404:402-407.

43. Lipsky, P.E. 2001.Systemic lupus erythematosus: an autoimmune disease of B cell hyperactivity. Nat. Immunol. 2:764-766.

44. Diamond, B. 2001. B cells. In Kelly's Textbook of Rheumatology. 6th edition. S. Ruddy, E.D. Harris, C.B. Sledge, editors. W.B. Saunders Company. Philadelphia, Pennsylvania, USA. 131-149.

45. Klinman, D.M., and Steinberg, A.D. 1987. Systemic autoimmune disease arises from polyclonal B cell activation. J. Exp. Med. 165:1755-1760. 